\title{
Military Conflict and the Rise of Urban Europe*
}

\author{
Mark Dincecco $^{\dagger} \quad$ Massimiliano Gaetano Onorato ${ }^{\ddagger}$
}

March 9, 2016

\begin{abstract}
We present new evidence about the relationship between military conflict and city population growth in Europe from the fall of Charlemagne's empire to the start of the Industrial Revolution. Military conflict was a main feature of European history. We argue that cities were safe harbors from conflict threats. To test this argument, we construct a novel database that geocodes the locations of more than 800 conflicts between 800 and 1799. We find a significant, positive, and robust relationship that runs from conflict exposure to city population growth. Our analysis suggests that military conflict played a key role in the rise of urban Europe.
\end{abstract}

Keywords: warfare, cities, political and economic development, Europe JEL codes: C20, O10, N40, N90, P48, R11

\footnotetext{
${ }^{*}$ We thank editor Oded Galor and three anonymous referees for valuable comments. Similarly, we thank Pablo Beramendi, Timothy Besley, Carles Boix, Roberto Bonfatti, Eltjo Buringh, Eric Chaney, James Fearon, Jeffry Frieden, Edward Glaeser, Philip Hoffman, Horacio Larreguy, James Morrow, Tommaso Nannicini, Nathan Nunn, Margaret Peters, Hugh Rockoff, Jean-Laurent Rosenthal, Kenneth Shepsle, Ugo Troiano, Julian Wucherpfennig, Jan Luiten van Zanden, Daniel Ziblatt, Fabrizio Zilibotti, and seminar participants at Birmingham, Bristol, Harvard, Harvard PIEP, LSE, Michigan, Modena, NES, Nottingham, PSE, UCL, and numerous conferences. We thank Maarten Bosker, Eltjo Buringh, and Jan Luiten van Zanden for generous data-sharing, and Nicola Fontana, Giovanni Marin, Michael Rochlitz, Nicole Scholtz, and Kerby Shedden for excellent data help. Finally, we thank the National Science Foundation for financial support through grant SES-1227237.

†University of Michigan; dincecco@umich.edu

‡IMT Lucca; m.onorato@imtlucca.it
} 


\section{Introduction}

The economic rise of Europe is a watershed historical event. Many scholars argue that cities played a central role in this rise (e.g., Smith, 1776, Weber, 1922, Pirenne, 1925, Mumford, 1960, Bairoch, 1988, Hohenberg and Lees, 1995, Glaeser, 2011). One thousand years ago, the urbanization rate in Europe was less than 4 percent. Even Rome was only 5 to 10 percent of its size under the Roman Empire. By the start of the Industrial Revolution, however, Europe had become highly urbanized (van Bavel et al., 2013, p. 392, 394).

What explains Europe's dramatic urban growth? This paper analyzes a main feature of European history: military conflict. According to Tilly (1992, p. 72), early modern Europe was at war in 78 to 95 percent of all years. In this context, historical cities were "safe harbors" from conflict threats (Glaeser and Shapiro, 2002). Historical cities held key defensive advantages over rural areas (e.g., fortifications). In the words of Adam Smith (1776, p. 250): "The inhabitants of cities and burghs, considered as single individuals, had no power to defend themselves; but by entering into a league of mutual defence with their neighbours, they were capable of making no contemptible resistance." We argue that, to escape the destructive effects of warfare, rural inhabitants under the threat of conflict relocated to cities. To the best of our knowledge, this paper is the first city-level analysis of the relationship between military conflict and urban growth.

To test this argument, we construct a novel database that spans the fall of Charlemagne's empire to the start of the Industrial Revolution. We identify the geographic locations of all conflicts fought on land in Europe from 800 to 1799. In total, our data include more than 800 conflicts and nearly 700 cities. To measure city exposure to conflict threats, we geocode conflict and city locations at the local (grid cell) level. The results of our econometric analysis show a positive and significant relationship that runs from conflict exposure to city population growth. We find that conflict exposure was associated with a 6-11 percent average increase in city populations per century. To put such magnitudes into perspective, average per-century city population growth between 800 and 1800 was 22 percent. Our most conservative estimate thus suggests that conflict-related city population growth was responsible for roughly one-quarter of average per-century city population growth over this period. 
We show evidence that this relationship is robust. Our benchmark model accounts for time-invariant local characteristics and widespread shocks through fixed effects. To further address the possibility of omitted variable bias, we modify the benchmark model to include country-century interaction effects, which help account for the evolution of country-level features (e.g., nation-state building), and grid-cell specific time trends, which help account for unobservable time-varying local features (e.g., rural-urban wage differences). In addition, we interact century fixed effects with observable time-invariant local characteristics (e.g., Atlantic trade potential) that may influence city population trends. Finally, we control for city-level observable features including urban networks and political, educational, and religious characteristics.

Larger cities may be more attractive targets for attackers. Country-century interaction effects and grid-cell specific trends help account for demographic trends at the national and local levels, respectively. To further address the possibility of reverse causation from urban size to conflict exposure, we control for pre-existing trends and mean reversion effects by interacting initial city populations with century fixed effects. In addition, we perform placebo tests and other tests for reverse causation. Such tests provide further evidence that the direction of causation runs from conflict exposure to city population growth and not vice versa.

To complete our analysis of the safe harbor effect, we present evidence on conflict types and on city walls.

Our paper contributes to the literature on the historical origins of state capacity. Warfare is a prominent explanation for nation-state formation in Europe (Tilly, 1975, 1992, Mann, 1986, Brewer, 1989, Downing, 1992, Besley and Persson, 2009, Gennaioli and Voth, 2014). Tilly's (1975, p. 42) famous statement is: "War made the state, and the state made war." According to the standard account, governments made institutional reforms that enabled them to finance military efforts and defend against survival threats. What this literature tends to overlook, however, is that institutional innovations at the city level were often historical precursors to state-level innovations (Stasavage, 2011, Blaydes and Paik, 2015). Our results show that before "war made the state," war helped "make the city" by driving rural inhabitants under the threat of conflict to relocate behind urban fortifications. In this way, our results improve our understanding of the state formation 
process.

In a related manner, our paper contributes to the literature on the historical origins of economic development. Scholars have linked historical warfare and state formation with modern prosperity (Bates, 2010, O’Brien, 2011, Rosenthal and Wong, 2011, Dincecco and Prado, 2012, Voigtländer and Voth, 2013a,b). As described, our results show that warfare helps explain the historical transformation from countryside to city. Urban density facilitates economic activity by reducing the costs of exchange for goods, labor, and ideas (Glaeser, 2011). Our results imply that warfare promoted historical development by driving rural inhabitants into cities where they could take advantage of agglomeration economies. In this regard, our paper offers a new way to understand the economic rise of urban Europe.

The paper proceeds as follows. The next section develops our argument. Section 3 describes the database and measurement. Section 4 presents the econometric methodology and the main results. Sections 5 tests for robustness. Section 6 presents further evidence. Section 7 concludes.

\section{Conceptual Framework}

This section performs two tasks. First, we discuss the relationship between military conflict and city population growth in European history, with a focus on the safe harbor effect. Second, we describe factors beyond military conflict that may help explain historical urbanization.

\subsection{Military Conflict and City Growth}

\subsubsection{Safe Harbor Effect}

Scholars trace urbanization in medieval Europe to the ninth-century break-up of Charlemagne's empire (Rosenthal and Wong, 2011, Stasavage, 2011). ${ }^{1}$ The number of indepen-

\footnotetext{
${ }^{1}$ City founding years often long preceded the fall of Charlemagne's empire. Boone (2013, p. 221) writes: "Broaching the subject of the origins of medieval urban Europe may wrongly suggest that the city was a totally new phenomenon in European history. In fact, in many cases medieval urbanity was built on a solid urban tradition, at least in those parts of Europe heavily influenced by the Roman Empire or Romanitas." After the fall of the Roman Empire, urban centers typically saw decay, but did not typically disappear (Boone, 2013, p. 222). In addition, new cities were founded during the medieval era throughout Europe
} 
dent states in Europe grew from less than 10 in 800 to more than 200 by 1300 (van Zanden, 2009 , p. 33). Political fragmentation created instability and warfare, which van Zanden (2009, p. 34) describes as follows: "This decentralization of political power often resulted in continuous warfare among the local lords, but at the same time led to an intensification of power at the local level."

Urban fortifications enabled rural populations to escape from some of the most destructive effects of medieval warfare (Smith, 1776, Pirenne, 1925, Mumford, 1960, Hohenberg and Lees, 1995, Rosenthal and Wong, 2011). Glaeser and Shapiro (2002, p. 208) write:

The first, and probably most important, interaction between warfare and urban development is that historically cities have provided protection against land-based attackers. Cities have the dual advantages of large numbers and walls and thus, holding the size of the attack constant, it is much better to be in a city than alone in the hinterland. Indeed, the role of cities in protecting their residents against outside attackers is one of the main reasons why many cities developed over time.

Glaeser and Shapiro (2002) call this effect the "safe harbor effect." In medieval Europe, scale advantage was key to military victory (Glaeser and Shapiro, 2002). Urban fortifications - including outer rings of conjoined dwellings, defensive palisades or ramparts, and fortified walls - were difficult to break through or surmount, enabling small groups of defenders to fend off even large groups of attackers (Tracy, 2000b). Mumford (1960, p. 250) states: "Against sudden raids a wall, on guard at all hours, was more useful than any amount of military courage." Furthermore, urban fortifications engendered a scale economy. As city size increased, there was a sharp drop in the required amount of fortifications per person (Glaeser and Shapiro, 2002).

Military campaigns could inflict numerous costs on rural populations. There was manpower losses in the fields, first because peasants were war recruits and second due to campaign-related deaths (Gutmann, 1980, p. 75). Crops, farms, and homes were destroyed due to arson. Peasants were responsible for large tax burdens during conflicts and for repair costs for damages to physical infrastructure (Caferro, 2008, p. 187). Since including Central Europe (Livi-Bacci, 2000, p. 21-7). 
peasants had to billet soldiers, peacetime preparations for future campaigns were costly (Hale, 1985, p. 197). Hale (1985, p. 196) writes: “In terms of personal impact the burdens of war certainly afflicted the rural more than the urban population." Thus, to escape the most destructive effects of warfare, we may expect to observe rural inhabitants under the threat of conflict to relocate to cities. ${ }^{2}$

\subsubsection{Target Effect}

The safe harbor effect implies that there should be a positive relationship that runs from military conflict to city population growth. Glaeser and Shapiro (2002) also identify a "target effect" whereby larger cities were more attractive targets for attackers. Since urban density facilitates plunder, attackers will prefer large urban concentrations, ceteris paribus. According to this argument, the logic runs from city population size to military conflict (the opposite of the safe harbor effect). Furthermore, if a city did not possess the military might to protect its wealth, then the target effect may have led to urban destruction. In that case, we may expect to observe a negative relationship between military conflict and city population growth. Our econometric analysis ahead will account for the target effect.

\subsubsection{Other Effects}

Beyond the safe harbor effect, there are at least two other effects that may generate a positive relationship that runs from military conflict to city population growth. First, Henderson et al. (2015) identify a "rural poverty effect" in modern-day Sub-Saharan Africa whereby dry agricultural conditions induce rural inhabitants to migrate to cities in search of better economic opportunities. Similarly, in the context of European history, the destructive effects of warfare in the countryside may have promoted rural-urban migration. What distinguishes the safe harbor effect from the rural poverty effect is that the former effect is anticipatory (it should occur under the threat of conflict) whereas the latter effect is reactionary (it should occur in the aftermath of conflict). Second, Voigtländer and

\footnotetext{
${ }^{2}$ Anecdotes highlight the historical role of cities as safe harbors beyond Europe. For example, Reid (2012, pp. 3-4) writes about Sub-Saharan Africa: "Elsewhere, warfare has been one of the drivers of urbanization, especially in the Western half of the continent; in some areas, the roots of urbanization lie in itinerant royal camps comprising armies and their enormous entourages, whereas in other circumstances, communities have come together in fortified urban clusters for protection, a phenomenon associated particularly with the nineteenth century - among the Yoruba, for example, or the Nyamwezi." [Our italics]
} 
Voth (2013a,b) identify a "Malthusian effect" (also see Galor and Weil, 2000) in which a large shock (the Black Death of 1348-50) reduced the rural population and thereby increased rural wages (where a fixed amount of land is an important factor of production). Higher wages increased the demand for manufactures produced in cities, which in turn promoted urbanization. We will provide specific evidence for the safe harbor effect in Section 6 . However, we will not be able to rule out the role of the rural poverty effect or the Malthusian effect.

\subsection{Alternative Explanations}

Beyond military conflict, scholars highlight other factors that may help explain historical urbanization.

Initial conditions are one such factor. Rokkan (1975) argues that key river trade routes led to early urban growth. Tilly (1992) emphasizes early commercial activities. Abramson and Boix (2014) argue that urban clusters were most likely to form in productive agricultural zones. White (1962) and Andersen et al. (2015) relate the adoption of the heavy plow to greater urbanization in zones with clay soils. Motamed et al. (2014) find that a location's agricultural potential and transport costs influence the likelihood of urbanization. By contrast, Bleakley and Lin (2015) argue that locational fundamentals are not the only determinants of city sizes.

Another strand of literature highlights political factors. De Long and Shleifer (1993), Acemoglu et al. (2005), and van Zanden et al. (2012) link representative government, which they argue protected private property rights, with greater urbanization. However, Stasavage (2014) argues that, due to their oligarchic structures, self-governing cities had negative long-run consequences for urbanization.

Other scholars focus on human and social capital. Dittmar (2011) shows evidence that urbanization was fastest where the moveable type printing press, which promoted new merchant skills, was adopted. Using city-level data, Cantoni and Yuchtman (2014) find that university training improved legal infrastructure and reduced trade costs. Greif and Tabellini (2010) argue that weak kin relations led to urban growth as a way to facilitate wide-scale cooperation. Guiso et al. (2008) show evidence that the medieval establishment of free cities had consequences for the development of social capital. 
Nunn and Qian (2011) highlight the seventeen-century introduction of the potato to the Old World, which can improve agricultural productivity and increase the returns to urban manufacturing. Furthermore, the potato's positive productivity shock can increase per capita income, which is positively linked with urbanization. Iyigun et al. (2010) show that there is a negative relationship between the introduction of the potato and violent conflict in Old World regions that were suitable to potato cultivation.

Our econometric analysis ahead will account for these sorts of economic, geographic, political, and social factors.

\section{Data}

Our urban population data are from Bairoch et al. (1988), who provide city population data for all European cities that ever reached 5,000 inhabitants between 800 and 1800 at century intervals for 800 to 1700 and half-century intervals for 1750 to $1850 .^{3}$ To help maintain estimation intervals of equal lengths, we focus our analysis on century (rather than the half-century) intervals. ${ }^{4}$ Our city population sample runs from 900 , just after the ninth-century fall of Charlemagne's empire, to 1800, just before the start of the Industrial Revolution in Continental Europe. ${ }^{5}$ We linearly interpolate (but never extrapolate) missing observations. To account for city-level features, we merge the Bairoch et al. data with data from Bosker et al. (2013), which leaves us with an unbalanced panel of 676 cities. $^{6}$

\footnotetext{
${ }^{3}$ Thus, we use all available population data, including for cities with less than 5,000 inhabitants at some point in time. Table A2 of the online appendix shows the result for the most stringent specification (i.e., column 4 of Table 3) when we (i) exclude cities that never reached 10,000 inhabitants and (ii) only include city-century observations for city populations greater than or equal to 10,000 . For (i), the estimate for $C_{i, g, t-1}$ is 0.067 , with p-value 0.031. For (ii), the estimate for $C_{i, g, t-1}$ is 0.063 , with p-value 0.057 (we lose nearly 40 percent of observations). Table $\mathrm{A} 9$ of the online appendix shows the result for the most stringent specification when we normalize per-century city populations according to Black and Henderson (1999). The estimate for $C_{i, g, t-1}$ is 0.092 , with p-value 0.020 .

${ }^{4}$ The Bairoch et al. data do not include 1100. Thus, we interpolate (but never extrapolate) observations for 1100. de Vries (1984) is an alternative data source for European historical urban populations. However, the de Vries data do not start until 1500. Bosker et al. (2013) compare the Bairoch et al. and de Vries data for each century from 1500 to 1800 . They find very similar estimates for urban populations; the correlation coefficients range between 0.986 and 0.992 .

${ }^{5}$ The nature of warfare changed dramatically over the nineteenth century due to improvements in transport and communications technologies and the rise of the mass army (Onorato et al., 2014).

${ }^{6}$ We updated the urban population data according to Bosker et al. (2013) for Bruges, Cordoba, London, Palermo, and Paris.
} 
Our historical conflict data are from Bradbury (2004) and Clodfelter (2002). ${ }^{7}$ Bradbury (2004) provides data on all military conflicts in the medieval West. The Bradbury data are organized into chapters, each of which covers a different geographical area of medieval warfare. Within each chapter, there is a summary of each military conflict fought, including a description of the conflict's location, approximate date, and type. The Bradbury data end in 1525 . We use the Bradbury data for military conflicts over 800-1499. The Clodfelter data start in 1500; we use these data for military conflicts over 1500-1799. The Clodfelter data are organized into chapters by century and geographical area. We focus on military conflicts fought in Europe.

The historical conflict data may be subject to measurement error. Even if Bradbury and Clodfelter are unable to record all conflicts, however, it is likely that they include the most important conflicts as documented by historians. Still, the quality of data documentation may differ by place. To help account for local differences in data quality, our econometric analysis ahead will always include city fixed effects.

Our unit of analysis for military conflict is an individual conflict (e.g., battle, siege), which could be a one-off event or part of a larger war. The Bradbury data categorize military conflicts as individual conflicts. However, the Clodfelter data categorize military conflicts under war headings. Each war heading has an entry of several paragraphs that describe the war's details. To identify the locations of the individual conflicts that comprise each war, we read through each entry in Clodfelter and compiled a list of all individual conflicts. Table 1 displays an example using the Thirty Years' War (1618-48), which by our reading contains 37 individual conflicts.

Historical accounts cannot pinpoint the exact geographical locations of military conflicts. We thus approximate conflict locations by the settlement (i.e., hamlet, village, town, city) nearest to where they took place. This method is both feasible, given the lack of available historical information, and intuitive, because conflicts were typically named after nearby settlements. For example, according to the Bradbury data, the Battle of Mons-enPévèle was fought on July 18, 1304 between Philip IV of France and William of Jülich of Flanders. This battle took place near the commune of Mons-en-Pévèle in northern France.

\footnotetext{
${ }^{7}$ Tilly (1992) and Jaques (2007) are two other sources for historical conflict data, both of which support the argument that military conflict was a defining feature of European history.
} 
We thus assign the geographical coordinates of Mons-en-Pévèle to it $\left(50^{\circ} 28^{\prime} 49^{\prime \prime} \mathrm{N}, 3^{\circ} 6^{\prime}\right.$ $\left.11^{\prime \prime} \mathrm{E}\right)$.

Table 2 summarizes the historical conflict data. Military conflict was a key feature of European history: 847 land-based conflicts took place from 800 to 1799, for an average of 85 per century. The tenth century saw the least conflict, with 15 recorded conflicts, while the eighteenth century saw the most, with 295 . Breaking the data down by modern-day countries, France saw the most conflict over this period, at 165, followed by Italy (135), England (103), Germany (103), and the Low Countries of Belgium and the Netherlands (66).

To measure city exposure to military conflicts, we use $150 \mathrm{~km} \times 150 \mathrm{~km}$ grid-scale cells. ${ }^{8}$ This size of grid cell roughly corresponds with NUTS2 units (e.g., county, province, region), the basic unit of economic territory devised by Eurostat, the statistical office of the European Union. To provide a sense of perspective, the Tuscany region in the centernorth of Italy is roughly $150 \mathrm{~km} \times 150 \mathrm{~km}$. Florence, the capital of Tuscany, is located near the center of this region. The distance from Florence to Livorno, the region's main port on the Tyrrhenian Sea, is roughly 90 kilometers as the crow flies. Reyerson (1999) claims that fourteenth-century horseback travel in Italy could cover 50 kilometers per day. ${ }^{9}$ Thus, we estimate that the historical travel time by horseback between Florence and Livorno was less than two days. Another example is the distance from Siena, also located near the center of Tuscany, to Grosseto, a southern Tuscan port. This distance is roughly 77 kilometers as the crow flies. Thus, we believe that $150 \mathrm{~km} \times 150 \mathrm{~km}$ grid sizes are appropriate. ${ }^{10}$

We only include $150 \mathrm{~km} \times 150 \mathrm{~km}$ grid cells that fall (at least partially) within the borders of modern countries for which there is at least one sample city. 196 grid cells

\footnotetext{
${ }^{8}$ We use a cylindrical equal area map projection with geometric center (longitude, latitude $)=(10.00735$, 46.76396), near Davos, Switzerland. Figure 1 displays data in the projection of analysis.

${ }^{9}$ Reyerson (1999) claims that medieval horseback travel from Paris to the Mediterranean coast, a distance of approximately 750 kilometers, took 12 days. At a rate of 50 kilometers per day, this trip would take 15 days. This duration is roughly in line with Reyerson's claim about medieval horseback travel time for Italy.

${ }^{10}$ Table A8 of the online appendix shows the results for the fixed effects specification (i.e., column 1 of Table 3 ) and the most stringent specification (i.e., column 4 of Table 3) when we use $75 \mathrm{~km} \times 75 \mathrm{~km}$ grid cells. For the fixed effects specification, the estimate for $C_{i, g, t-1}$ is 0.153 , with p-value 0.002 . For the most stringent specification, the estimate for $C_{i, g, t-1}$ is 0.049 , with p-value 0.095 .
} 
include at least one sample city. 95 percent of total conflicts between 800 and 1799 fall within a grid cell that contains at least one sample city. To put it differently, only 5 percent of conflicts do not fall within a grid cell that contains at least one sample city. These conflicts are rather distant from any sample city (e.g., they are located in Ukraine, Finland, Norway, or Sweden).

90 percent of grid cell-centuries saw 0 or 1 conflicts from 800 to 1799 . Thus, in line with the approach taken by Besley and Reynal-Querol (2014), we construct a dummy variable for each grid cell that equals 1 if there was (at least one) military conflict in that cell for each century from 800 to 1799 , and 0 otherwise. ${ }^{11}$ This approach reduces the influence of unobservable factors that can affect the total number of conflicts to which sample cities were exposed. 95 percent of grid cell-centuries saw 0, 1, or 2 conflicts from 800 to 1799. Thus, as an alternative, we construct an ordered variable for conflict exposure that assigns a value of 0 to each century that a grid cell saw peace, a value of 1 to one conflict, and a value of 2 to two or more conflicts.

Figure 1 maps the 847 conflicts (circles) between 800 and 1799 along with the 676 cities (triangles) that we will exploit in this analysis.

\section{Econometric Analysis}

\subsection{Methodology}

The linear specification that we estimate is

$$
P_{i, g, t}=\alpha+\beta C_{i, g, t-1}+\mu_{i}+\lambda_{t}+\gamma^{\prime} \mathbf{X}_{\mathbf{i}, \mathbf{g}, \mathbf{t}}+\epsilon_{i, g, t}
$$

where $P_{i, g, t}$ is $\log$ population for city $i$ in grid cell $g$ at century $t, C_{i, g, t-1}$ is the conflict dummy that equals 1 if there was a military conflict in grid cell $g$ over the previous century, $\mu_{i}$ and $\lambda_{t}$ are city and century fixed effects, $\mathbf{X}_{\mathbf{i}, \mathbf{g}, \mathbf{t}}$ is a vector of city-level controls that we will include in a robustness check, and $\epsilon_{i, g, t}$ is a random error term. ${ }^{12}$ All stan-

\footnotetext{
${ }^{11}$ Table 2 shows the shares of sample cities and grid cells that saw (at least one) conflict by century. On average, 27 percent of cities and 19 percent of grid cells saw conflict over 800-1799. The smallest share of cities saw conflict over the tenth century ( 9 percent), while the largest share saw conflict over the eighteenth century (54 percent). Similarly, the smallest share of grid cells saw conflict over the tenth century ( 6 percent), while the largest share saw conflict over the eighteenth century (43 percent).

${ }^{12}$ Thus, the first observation of $P_{i, g, t}$ is for 900 , because the first observation of $C_{i, g, t-1}$ measures conflict exposure over 800-99.
} 
dard errors are robust, clustered at the grid cell level to account for any within-grid serial correlation in the error term. ${ }^{13}$ Table A1 of the online appendix displays the descriptive statistics for the regression variables.

Our benchmark modeling approach accounts for unobserved features that may influence city population growth and conflict exposure alike. City fixed effects help account for initial conditions and time-invariant characteristics. Century fixed effects help account for widespread shocks. However, methodological challenges remain.

A first concern is omitted variable bias. There may be unobserved time-varying factors that influence city population growth. We address this concern in several ways. First, we modify our benchmark model to include country-century interaction effects, which help account for changes in country-level variables, including total populations, urbanization rates, economic activity, and nation-state building. Second, we include grid cell-specific time trends, which help account for unobservable local features that change over time, including rural-urban wage differences and urban amenities. Third, we interact century fixed effects with a variety of observable time-invariant city characteristics, including Atlantic trade potential, soil quality, terrain ruggedness, and potato cultivation. Fourth, we control for observable time-varying city features, including urban networks, political institutions, university hosts, and bishop or archbishop seats.

A second concern is reverse causation. As described, Glaeser and Shapiro (2002) identify a target effect whereby larger cities may be more attractive targets. We address this concern as follows. First, country-century interaction effects and grid-cell specific trends control for demographic trends at the national and local levels, respectively. Second, to further account for pre-existing trends and mean reversion effects, we include initial log city population-century interaction effects. ${ }^{14}$ Third, we perform placebo tests equal to the first lead of our variable of interest. Fourth, we regress (future) conflicts on lagged city populations.

\footnotetext{
${ }^{13}$ Table A15 of the online appendix shows the results when we adjust standard errors for spatial correlation according to Conley (1999) for the most stringent specification (i.e., column 4 of Table 3). To compute spatial correlation-adjusted standard errors, we follow the routine in Fetzer (2014), who extends Hsiang (2010). We assume that spatial correlation linearly decreases in the distance between each sample city up to cutoffs of $100 \mathrm{~km}, 200 \mathrm{~km}, 300 \mathrm{~km}, 400 \mathrm{~km}$, or $500 \mathrm{~km}$, respectively. The estimates for $C_{i, g, t-1}$ are unchanged, with p-values that range from 0.003 to 0.004 .

${ }^{14}$ Initial log city populations refer to the first available observation for each sample city.
} 


\subsection{Main Results}

Table 3 presents our estimates for the relationship between conflict exposure and city population growth. City fixed effects help account for initial conditions (economic, demographic, political, social) and local geographical features that may influence conflict patterns. Century fixed effects help control for common shocks across time. Column 1 shows the results for this benchmark specification. There is a significant relationship (at the 1 percent level) between military conflicts that took place within the same $150 \mathrm{~km} \mathrm{x}$ $150 \mathrm{~km}$ grid cell in which a city was located and city populations. Conflict exposure was associated with a 11 percent average increase in city populations.

City and century fixed effects help account for unobserved features that were constant for each city and across each century. To account for changes over time in country-level variables, column 2 adds country-century interaction effects. The estimate for conflict exposure is similar in magnitude and significance as the benchmark case. To control for unobserved factors that may have had time-varying local consequences for urbanization patterns (e.g., the Black Death), column 3 adds grid cell-specific time trends. The result for conflict exposure remains significant; the point estimate falls to 6 percent. ${ }^{15}$

City fixed effects help control for initial demographic conditions. Country-century interaction effects and grid-cell specific trends help control for national and local demographic trends, respectively. Still, it is possible that cities with larger or smaller initial populations grew at different rates. To control for pre-existing trends and mean reversion effects, column 4 adds initial log city population-century interaction effects. Including initial log city population-century interaction effects is a demanding way to account for pre-existing trends and mean reversion effects (Acemoglu et al., 2011). The estimate for $C_{i, g, t-1}$ is significant at the 5 percent level, with a point estimate of 7 percent.

\footnotetext{
${ }^{15}$ Table $\mathrm{A} 3$ of the online appendix shows the result for the most stringent specification (i.e., column 4 of Table 3) when we add city-specific time trends (rather than grid cell-specific time trends). The estimate for $C_{i, g, t-1}$ is 0.044 , with p-value 0.083 (standard errors clustered at city level) or p-value 0.147 (standard errors clustered at grid-cell level). Given that our dependent variable $P_{i, g, t}$ is in logs, the grid cell-specific (or city-specific) time trends capture exponential trends (Wooldridge, 2009, p. 361). Still, Table A3 of the online appendix shows the results for the most stringent specification when we add a quadratic time trend at the city level or grid-cell level. For the former, the estimate for $C_{i, g, t-1}$ is 0.039 , with $p$-value 0.139 (standard errors clustered at city level) or p-value 0.208 (standard errors clustered at grid-cell level). For the latter, the estimate for $C_{i, g, t-1}$ is 0.038 , with $\mathrm{p}$-value 0.165 .
} 
Overall, Table 3 shows evidence for a significant relationship that runs from conflict exposure to city population growth in Europe from the fall of Charlemagne's empire to the start of the Industrial Revolution. The results are robust to a variety of checks for omitted variable bias and reverse causation.

\section{Robustness}

The evidence that we have shown in the previous section supports the argument that cities were safe harbors in European history. In this section, we use a variety of techniques to further test the robustness of our results. First, we control for a range of observable city characteristics that may have influenced city population trends. Second, we perform placebo tests and other tests for a target effect. Finally, we assess how robust our estimates are to sample changes and an alternative conflict exposure measure.

\subsection{Controls for Observables}

\subsubsection{Atlantic Trade}

Acemoglu et al. (2005) show evidence that Atlantic traders (Britain, France, the Netherlands, Portugal, Spain) saw significantly faster urbanization rates from 1500 onward. To account for the rise of Atlantic trade on city population growth, column 1 of Table 4 interacts Atlantic port cities with century dummies in the most stringent specification (i.e., column 4 of Table 3). The result for conflict exposure is robust to the inclusion of Atlantic port city-century interaction effects, with a point estimate of 7 percent. ${ }^{16}$

\subsubsection{Heavy Plow}

White (1962) and Andersen et al. (2015) argue that the breakthrough adoption of the heavy plow in 1000 led to greater urbanization in European regions with clay soils. To

\footnotetext{
${ }^{16}$ Given network effects, Atlantic trade may have been important for cities near, but not along, the Atlantic coast. Table A7 of the online appendix shows the result that interacts Atlantic coast grid cells with century fixed effects for the most stringent specification (i.e, column 4 of Table 3). The estimate for $C_{i, g, t-1}$ is 0.049 , with p-value 0.076. This table also shows the result for Atlantic coast grid cells and neighboring grid cells. The estimate for $C_{i, g, t-1}$ is very similar as before. To account for Hanseatic trade, we code Hanseatic cities according to the list in Dollinger (1964, pp. ix-x). Table A7 of the online appendix shows the results that interact Hanseatic cities or Hanseatic grid cells with century fixed effects. The estimates for $C_{i, g, t-1}$ range from 0.068 to 0.069 , with p-values that range from 0.027 to 0.029 .
} 
control for technological changes in agriculture on city population growth, column 2 of Table 4 interacts local soil quality according to Bosker et al. (2013) with century dummies. The soil quality data use climate information to calculate the probability that a region can be cultivated. ${ }^{17}$ The estimate for $C_{i, g, t-1}$ is similar in magnitude and significance to the previous specification. ${ }^{18}$

\subsubsection{Potato Cultivation}

Nunn and Qian (2011) show that the introduction of the potato can account for a significant portion of urbanization in the Old World between 1700 and 1900. Similarly, Iyigun et al. (2010) find a negative relationship between the introduction of the potato and violent conflict in regions suitable to its cultivation. In the context of China, Jia (2014) shows that the introduction of the potato reduced the likelihood of peasant revolt in drought years. Column 3 of Table 4 interacts local soil suitability for potato cultivation with century dummies. ${ }^{19}$ The results for conflict exposure are again similar as before.

\subsubsection{Ruggedness}

Hohenberg and Lees (1995) note that, for defensive purposes, city locations were often in difficult-to-reach places. Column 4 of Table 4 interacts local terrain ruggedness, another geographical feature from Bosker et al. (2013), with century dummies. The ruggedness data calculate the standard deviation of the elevation of the terrain that surrounds each sample city for a radius of $10 \mathrm{~km}$. The estimate for conflict exposure is robust to the inclusion of ruggedness-century interaction effects.

\footnotetext{
${ }^{17}$ These data are available for grid cells of roughly $55 \mathrm{~km}$ x $40 \mathrm{~km}$. Bosker et al. match the soil quality data to cities based on latitudes and longitudes.

${ }^{18}$ Andersen et al. (2015) provide data on soil suitability for a plow-positive crop (barley) for NUTS2 units, which we match to sample cities in our database. We test three levels of barley suitability: (i) high, where Andersen et al.'s suitability index exceeds 70, (ii) good, where this index exceeds 55, and (iii) medium, where this index exceeds 40. Table A14 of the online appendix shows the results when we interact soil suitability for barley with century fixed effects for the most stringent specification (i.e., column 4 of Table 3). The estimates for $C_{i, g, t-1}$ range from 0.069 to 0.072 , with p-values that range from 0.034 to 0.045 .

${ }^{19}$ To construct the potato suitability data, we follow the Nunn-Qian procedure. First, we match the GIS raster file with global coverage of soil suitability for potato cultivation to each $150 \mathrm{~km} \times 150 \mathrm{~km}$ grid cell in our database. There are five categories of potato suitability: (i) very suitable land, (ii) suitable land, (iii) moderately suitable land, (iv) marginally suitable land, and (v) unsuitable land. Nunn and Qian define land to be suitable for potato cultivation if it falls within categories (i) to (iii). Finally, we define potato suitability as Potato $_{i, g} \equiv \ln \left(1+\right.$ Potato Area $\left._{i, g}\right)$.
} 


\subsubsection{Other Geographic Features}

The local returns to time-invariant geographical features may change over time. For example, improvements to maritime technology may have changed the returns to sea or river locations. Column 5 of Table 4 interacts the variables from columns 1 to 4 (Atlantic ports, soil quality, soil suitability for potato cultivation, and ruggedness) along with a variety of other local geographic characteristics (seaports, riverports, Roman road hubs, and elevations above sea level) with century fixed effects. ${ }^{20}$ The result for conflict exposure is similar in magnitude and significance as before.

\subsubsection{Time-Varying City-Level Features}

Distances to other cities may influence urbanization patterns. City fixed effects control for distances between cities. Grid-cell specific trends help control for changes in urban networks and transportation technology over time. As an additional way to account for urban clusters, we control for the number of cities with populations of at least 10,000 that were located within $100 \mathrm{~km}$ of each sample city per century. To account for political institutions, we include a dummy variable for whether a city was a self-governing commune each century. To account for education, we include a dummy variable for whether a city hosted a university each century. To account for religion, we control for whether a city was a bishop or archbishop seat each century. We code the city-level variables according to Bosker et al. (2013). ${ }^{21}$

Column 6 of Table 4 adds these time-varying city-level controls. The estimate for $C_{i, g, t-1}$ remains significant; the point estimate falls to 5 percent. Dense urban networks and self-governing communes were associated with significant increases in city populations.

Column 7 of Table 4 includes the interaction terms from columns 1 to 5 (Atlantic ports, soil quality, soil suitability for potato cultivation, ruggedness, and local geography) along with the city-level controls. The estimate for conflict exposure is similar in magnitude and significance to the previous specification.

\footnotetext{
${ }^{20}$ The data for the other geographic variables are from Bosker et al. (2013).

${ }^{21}$ Note that these variables are "bad" controls (Angrist and Pischke, 2009) in the sense that they themselves may be outcomes of military conflict.
} 


\subsection{Placebo Tests}

To this point, we have shown evidence for a robust relationship that runs from conflict exposure to city population growth. To further test the strength of this relationship, we create a conflict exposure placebo equal to the first lead of our exposure measure. For example, if the dependent variable $P_{i, g, t}$ measures $\log$ population for city $i$ in grid cell $g$ in 1500, then the conflict exposure placebo measures conflict exposure over 1500-1599 (in contrast to the original conflict exposure measure $C_{i, g, t-1}$, which measures conflict exposure over 1400-1499). If the placebo coefficient is not significant, then this analysis will provide further evidence in favor of our preferred interpretation of the results.

Column 1 of Table 5 shows the result for the one-century conflict exposure placebo for the most stringent specification. The point estimate for the conflict exposure placebo is 0.036 ; the p-value is 0.281 . For comparison, if we estimate this specification for the original conflict exposure measure for the same set of observations as for the placebo sample, the point estimate (0.072) is twice the size of the placebo estimate and is highly significant (not shown).

Column 2 shows the result when we exclude the capital city and largest city today for each sample country. The point estimate for the conflict exposure placebo is now 0.027; the p-value is 0.423 . Excluding the largest 10 sample cities (column 3) or 20 sample cities (column 4) each century between 800 and 1800 does not change the placebo test results, either.

Glaeser and Shapiro (2002, p. 211) note that a target effect was less likely if a city had the military strength to protect its wealth. Column 5 shows the result when we restrict the sample to cities that were ever self-governing communes, where military strength was likely to have been greater (Shultz and Weingast, 1998, Stasavage, 2011). Consistent with Glaeser and Shapiro's claim, the point estimate for the conflict exposure placebo falls to 0.010 ; the $\mathrm{p}$-value rises to 0.789 .

Overall, the placebo tests reinforce our preferred interpretation of the results. 


\subsection{Target Effect Test}

We control for demographic trends in several ways (e.g., country-century interaction effects, grid-cell specific trends, initial log city population-century interaction effects). To explicitly test for the target effect, we regress the conflict exposure measure $C_{i, g, t-1}$ on lagged city populations. For example, if the dependent variable $C_{i, g, t-1}$ measures conflict exposure over 1400-1499, then $P_{i, g, t-1}$ measures lagged log city populations in 1400 . This test is a way to evaluate whether larger cities are more attractive targets. Column 1 of Table 6 shows the results of this analysis for the most stringent specification when the independent variable is $P_{i, g, t-1}$. Column 2 repeats this test when the independent variables are $P_{i, g, t-1}$ and $P_{i, g, t-2}$. The coefficients for lagged city populations are not significant in either specification. Columns 3 to 6 show the results when we exclude (i) the capital city and largest city today for each sample country (column 3), (ii) the largest 10 sample cities each century (column 4), (iii) the largest 20 sample cities each century (column 5), or (iv) non self-governing communes (column 6). Relative to the first two columns, the coefficients for lagged city populations are smaller and the p-values are larger in columns 3, 4, and 6 , and of similar size in column 5.22 This exercise provides further evidence that the target effect does not drive our results. ${ }^{23}$

\footnotetext{
${ }^{22}$ To test whether larger cities were more attractive targets over the short term, Table A12 of the online appendix shows the results of the target effect test when we regress the conflict exposure measure $C_{i, g, t-1}$ on lagged city populations $P_{i, g, t-1}$, where $C_{i, g, t-1}$ now equals 1 if there was a military conflict in grid cell $g$ over the first $z$ years of century $t$, where $z=10,20,30,40,50$. The coefficients for $P_{i, g, t-1}$ are never significant.

${ }^{23}$ In the online appendix, we account for the target effect in another way, by including the lagged dependent variable and re-running the specifications from Table 3. Including the lagged dependent variable induces Nickell bias (Nickell, 1981), particularly if the panel's time dimension $T$ is small (for our sample, $T=8$ ). Still, Table A6 shows the main results when we include lagged log city population as a control. The estimates for $C_{i, g, t-1}$ range from 0.048 to 0.080 , with p-values that range from 0.005 to 0.140 (we lose 20 percent of observations). For comparison, the original estimates range from 0.063 to 0.113 , with pvalues that range from 0.004 to 0.055 . Thus, including lagged log city population does not change the main results by much. To address Nickell bias, we can use GMM estimation (Arellano and Bond, 1991). However, GMM requires strong assumptions (Angrist and Pischke, 2009, p. 245). Namely, GMM uses past differenced lags to instrument for the lagged dependent variable; it is unlikely that past differenced lags are not correlated with the differenced residuals. Still, Table A13 shows the main results when we use GMM. The estimates for $C_{i, g, t-1}$ range from 0.024 to 0.062 , with $\mathrm{p}$-values that range from 0.013 to 0.321 (we lose more than 35 percent of observations).
} 


\subsection{Alternative Samples}

\subsubsection{Exclude Britain}

Country-century interaction effects and grid-cell specific trends control for unobserved time-varying factors at the national and local levels, respectively. To further control for the influence of early industrialization, column 1 of Table 7 excludes British (along with Irish) cities for the most stringent specification. The results for conflict exposure are robust to this sample change. ${ }^{24}$

\subsubsection{Exclude Capitals}

To test for the importance of capital status, column 2 of Table 7 excludes grid cell-centuries that contain a historical sovereign capital city according to Bosker et al. (2013). The estimate for $C_{i, g, t-1}$ remains significant at the 1 percent level, with a point estimate of 11 percent. $^{25}$

\subsubsection{Exclude Centuries}

The 1700s saw over 35 percent of all sample conflicts. To further test - beyond century fixed effects - the influence of eighteenth-century conflicts, column 3 of Table 7 restricts the sample to conflicts from 800 to 1699 . The estimate for conflict exposure on city populations is similar as before.

Scholars including Tilly (1992), Parker (1996), and Gennaioli and Voth (2014) focus on the early modern era (from the fifteenth century onward) as a particularly important era of military conflict and state-building in Europe. Column 4 of Table 7 shows the result for this era. The estimate for $C_{i, g, t-1}$ remains robust. $^{26}$

\footnotetext{
${ }^{24}$ Figure A1 of the online appendix shows the results for the most stringent specification (i.e., column 4 of Table 3 ) when we exclude each country one by one (there are 26 countries). The estimates for $C_{i, g, t-1}$ range from 0.044 to 0.077 , with p-values that range from 0.014 to 0.098 ( 24 of $26 \mathrm{p}$-values are less than 0.050 ). The lowest point estimate (0.044) occurs when we exclude Spain. Still, this estimate remains significant at the 10 percent level. Over the medieval period, Christian rulers expelled Muslim invaders from Spain (the Reconquista). To defend newly recaptured territory, such rulers established fortified cities. To promote repopulation, they often granted individual freedoms to new urban inhabitants ( $\mathrm{O}^{\prime}$ Callaghan, 2002, pp. 699-700).

${ }^{25}$ Furthermore, excluding the capital city and largest city today for each sample country does not change the main results.

${ }^{26}$ The estimate for conflict exposure is positive but no longer significant when we restrict the conflict sample
} 


\subsection{Alternative Conflict Exposure Measure}

Our benchmark measure for conflict exposure is a dummy variable. As described in Section 3, the dummy approach makes sense because 90 percent of grid cell-centuries saw 0 or 1 conflicts from 800 to 1799 . 95 percent of grid cell-centuries saw 0,1 , or 2 conflicts from 800 to 1799 . Thus, as an alternative, we construct an ordered variable that takes a value of 0 for each century that a grid cell saw 0 conflicts, a value of 1 for 1 conflict, and a value of 2 for 2 or more conflicts. Table 8 shows the results for the ordered variable approach. The results are robust to this alternative conflict exposure measure. ${ }^{27}$

\subsection{Summary}

Overall, the robustness checks described in this section reinforce the validity of our main result, namely that there is a strong and significant relationship that runs from conflict exposure to city population growth in European history.

to the pre-early modern era (e.g., column 4 of Table A5 of the online appendix). Tilly (1992), Parker (1996), and Gennaioli and Voth (2014) highlight the importance of new urban fortifications in early modern Europe called the trace italienne. New fortifications may have reduced the probability of wartime urban destruction. For example, Bosker et al. (2013) provide data for the number of times that a sample city was plundered each century. Between the start of the ninth century and the end of the twelfth century, sample cities were plundered 105 times. However, between the start of the fifteenth century and the end of the eighteenth century, sample cities were only plundered 65 times. Furthermore, the most plundering (61 times) took place over the ninth century, while the least plundering ( 5 times) took place over the eighteenth century. This evidence suggests that post-fifteenth century improvements in defensive structures may have reduced the likelihood of wartime urban destruction, which may help explain why our results suggest that the safe harbor effect was more important during the early modern era than before. A related explanation is that the safe harbor effect may have become more important after the Black Death and the emergence of a post-Malthusian economy. Greater per capita income translated into greater tax revenues, which (i) increased the likelihood of military conflict (Voigtländer and Voth, 2013a,b) and (ii) may have increased the ability of polities to construct new fortifications, thereby reducing the likelihood of wartime urban destruction. This explanation is consistent with the result in column 5 of Table 5, which shows that a target effect was less likely if a city had the military strength to protect its wealth.

${ }^{27}$ Table A10 of the online appendix shows the result for the most stringent specification (i.e., column 4 of Table 3) when we use the number of conflicts and the squared number of conflicts as our variables of interest. The estimate for $C_{i, g, t-1}$ is 0.023 , with p-value 0.051 . The estimate for the quadratic term is -0.001 , with p-value 0.118 . The coefficient for the quadratic term is negative. However, (i) the magnitude is very small and (ii) the negative effect does not apply until 12 conflicts are reached. This number is large; nearly all sample cities were exposed to less conflict over 800-1799. 


\section{Further Evidence}

In this section, we present further evidence for the safe harbor effect. This evidence takes two forms. First, we distinguish between conflict types. Second, we offer evidence from the historical literature on city walls.

\subsection{Conflict Types}

Battles and sieges comprise 94 percent of our historical conflict data. Battles typically took place in the countryside or hinterland, whereas sieges typically took place just outside (and sometimes within) cities. Table 9 restricts the conflict sample to battles only (column 1) or sieges only (column 2) for the most stringent specification. For battles only, the estimate for $C_{i, g, t-1}$ is highly significant, with a point estimate of 0.065 . For sieges only, however, the estimate for $C_{i, g, t-1}$ is not significant, with a smaller point estimate (0.034). We believe that this evidence on conflict types is consistent with the safe harbor effect, because it suggests that, as our argument would predict, the safe harbor effect was stronger for conflicts that took place in the countryside or hinterland than for conflicts that took place just outside cities, which could cause greater urban destruction (and therefore less city population growth).

\subsection{Evidence from City Walls}

Fortified stone walls did not surround every city in medieval and early modern Europe (Tracy, 2000a, pp. 3-4, Tracy, 2000b, p. 77). ${ }^{28}$ For example, Tracy (2000b, table 3.7) estimates that 576 of 1,083 (or, 53 percent) of cities in Germany were walled between Roman times and 1800. ${ }^{29}$ The cost to erect fortified stone walls in terms of labor and materials was large (Tracy, 2000a, p. 3). For example, the basic fourteenth-century wall at Leiden in the Netherlands took 50 million bricks to build (Tracy, 2000b, p. 71). Fourteenth-century Lille, which Wolfe (2009, p. 65) labels a "typical" French case, spent 50 percent of yearly revenues on construction and maintenance costs for its city walls. Tracy $(2000 a, b)$ ar-

\footnotetext{
${ }^{28}$ As described in Section 2, a city without fortified walls could still have outer rings of conjoined dwellings that functioned as barriers, or could have defensive palisades or ramparts, or be situated in a naturally protected location, thereby enabling small groups of defenders to fend off larger groups of attackers.

${ }^{29}$ Tracy's definition of "walled city" counts single or double stone walls, gun platforms placed outside of walls, and bastioned traces, but excludes defensive palisades and ramparts.
} 
gues that improved security was the main reason why some city leaders decided to pay the price and erect fortified walls, writing (p. 3): "No matter how 'natural' it may have seemed for a town to have walls, the sheer labor and expense involved means that wall builders must have had compelling reasons. Most often, it was a matter of defense against anticipated attack." Reyerson (2000, p. 89) and Wolfe (2009, p. 60-1) claim that the beginning of the Hundred Years' War (1337-1453) was associated with significant wall-building efforts by French cities. Similarly, Wolfe (2000, p. 328) argues that the start of the French Wars of Religion (1562-98) began a "frenzy" of wall-building activity.

It is difficult to systematically assess which cities were walled in medieval and early modern Europe (Tracy, 2000b, p. 77). Germany is the best documented case (Tracy, 2000b, p. 77). Tracy (2000b, table 3.7) estimates the share of walled cities in total cities for historical German provinces. We combine the Tracy data on walled cities with data on conflict exposure between 800 and 1799 according to modern German states, which overlap with historical provinces. ${ }^{30}$ To compute our measure of conflict exposure, we sum the number of conflicts within each modern German state over this period. We then scale this number by the area of each modern German state. Figure 2 indicates that there is a positive relationship between warfare and walled cities in German history. Rhineland, the province with the most historical conflict exposure (0.55), has the second-highest share of walled cities (51 out of 73, or 70 percent). By contrast, Saxony and Schleswig-Holstein, the provinces with the least historical conflict exposure, have the lowest shares of walled cities. This evidence suggests that, as the safe harbor effect would predict, the historical relationship between warfare and city walls is positive. Furthermore, Tracy (2000b, tables 3.4-3.6) shows that the percentage of walled cities was relatively high (35-43 percent) among very small cities (less than 1,000 inhabitants), which suggests that security was a main function of city walls, even if there was not much wealth to protect.

Overall, while we still cannot rule out the roles of the rural poverty effect or the Malthusian effect to explain the historical relationship between military conflict and city

\footnotetext{
${ }^{30}$ The mappings from historical provinces to modern German states are approximations. Tracy presents data for eleven historical provinces, of which we exclude two (East Prussia and Silesia) that do not fall within the borders of modern Germany. Of the nine historical provinces that we include, we map Anhalt to the modern state of Saxony-Anhalt, Brandenburg to Brandenburg, Hesse to Hesse, Meckenburg and Pomerania to Mecklenburg-Vorpommern, Rhineland to Rhineland-Palatinate, Saxony (or, Old Saxony) to Lower Saxony, Schleswig-Holstein to Schleswig-Holstein, and Thuringia to Thuringia.
} 
population growth, the evidence that we present in this section provides further evidence for the safe harbor effect.

\section{Conclusion}

This paper presents new evidence about the relationship between military conflict and city population growth in Europe from the fall of Charlemagne's empire to the start of the Industrial Revolution. Military conflict was a defining feature of European history. Our argument follows a distinguished line of scholars that view historical cities as safe harbors from conflict threats.

To test our argument, we perform an econometric analysis on a novel database that spans 1,000 years. Our analysis accounts for potential biases from omitted variables and reverse causation. We show evidence for a positive, significant, and robust relationship that runs from conflict exposure to city population growth. Our estimates indicate that conflict exposure was associated with a 6-11 percent average increase in city populations.

To the best of our knowledge, our paper is among the first to provide systematic evidence that military conflicts played a key role in the rise of urban Europe. Does the legacy of historical conflict persist? Systematic study of the long-run consequences of historical conflict for urban prosperity in Europe is an exciting topic for future work. 


\section{References}

Abramson, S. and C. Boix (2014). "The Roots of the Industrial Revolution: Political Institutions or (Socially-Embedded) Know-How?" Working paper, Princeton University.

Acemoglu, D., S. Johnson, and J. Robinson (2005). "The Rise of Europe: Atlantic Trade, Institutional Change, and Economic Growth." American Economic Review, 94: 546-79.

Acemoglu, D., D. Cantoni, S. Johnson, and J. Robinson (2011). "The Consequences of Radical Reform: The French Revolution." American Economic Review, 101: 3286-307.

Andersen, T., P. Jensen, and C. Skovsgaard (2015). "The Heavy Plough and the Agricultural Revolution in Medieval Europe." Journal of Development Economics, 118: 133-49.

Angrist, J. and J.S. Pischke (2009). Mostly Harmless Econometrics, Princeton: Princeton University Press.

Arellano, M. and S. Bond (1991). “Some Tests of Specification for Panel Data: Monte Carlo Evidence and an Application to Employment Equations." Review of Economic Studies, 58: 277-97.

Bairoch, P. (1988). Cities and Economic Development. Chicago: Chicago University Press.

Bairoch, P., J. Batou, and P. Chèvre (1988). La Population Des Villes Européenes. Geneva: Librarie Droz.

Bates, R. (2010). Prosperity and Violence, Second Edition. New York: Norton.

Besley, T. and T. Persson (2009). "The Origins of State Capacity: Property Rights, Taxation, and Politics." American Economic Review, 99: 1218-44.

Besley, T. and M. Reynal-Querol (2014). "The Legacy of Historical Conflict: Evidence from Africa." American Political Science Review, 108: 319-336.

Black, D. and V. Henderson (1999). "Spatial Evolution of Population and Industry in the United States." American Economic Review, 89: 321-27.

Blaydes, L. and C. Paik (2015). "The Impact of Holy Land Crusades on State Formation: War Mobilization, Trade Integration, and Political Development in Medieval Europe." Forthcoming, International Organization. 
Bleakley, H. and J. Lin (2015). "History and the Sizes of Cities." American Economic Review Papers and Proceedings, 105: 558-63.

Boone, M. (2013). "Medieval Europe." In P. Clark, ed., The Oxford Handbook of Cities in World History, Oxford: Oxford University Press.

Bosker, M., E. Buringh, and J.L. van Zanden (2013). “From Baghdad to London: Unraveling Urban Development in Europe and the Arab World, 800-1800." Review of Economics and Statistics, 95: 1418-37.

Bradbury, J. (2004). The Routledge Companion to Medieval Warfare. London: Routledge.

Brewer, J. (1989). The Sinews of Power. London: Unwin Hyman.

Caferro, W. (2008). “Warfare and Economy in Renaissance Italy, 1350-1450." Journal of Interdisciplinary History, 39: 167-209.

Cantoni, D. and N. Yuchtman (2014). "Medieval Universities, Legal Institutions, and the Commercial Revolution." Quarterly Journal of Economics, 129: 823-87.

Clodfelter, M. (2002). Warfare and Armed Conflicts: A Statistical Reference, 1500-2000. Jefferson: McFarland.

Conley, T. (1999). “GMM Estimation with Cross-Sectional Dependence." Journal of Econometrics, 92: 1-45.

De Long, B. and A. Shleifer (1993). "Princes and Merchants: European City Growth Before the Industrial Revolution." Journal of Law and Economics, 36: 671-702.

de Vries, J. (1984). European Urbanization, 1500-1800. Cambridge: Harvard University Press.

Dincecco, M. and M. Prado (2012). "Warfare, Fiscal Capacity, and Performance." Journal of Economic Growth, 17: 171-203.

Dittmar, J. (2011). "Information Technology and Economic Change: The Impact of the Printing Press." Quarterly Journal of Economics, 126: 1133-72.

Dollinger, P. (1964). The German Hansa. Palo Alto: Stanford University Press.

Downing, B. (1992). The Military Revolution and Political Change. Princeton: Princeton Uni- 
versity Press.

Fetzer, T. (2014). "Can Workfare Programs Moderate Violence? Evidence from India." Working paper, London School of Economics.

Galor, O. and D. Weil (2000). "Population, Technology, and Growth: From the Malthusian Regime to the Demographic Transition and Beyond." American Economic Review, 90: $806-28$.

Gennaioli, N. and H.J. Voth (2014). "State Capacity and Military Conflict." Forthcoming, Review of Economic Studies.

Glaeser, E. (2011). Triumph of the City. New York: Penguin.

Glaeser, E. and J. Shapiro (2002). "Cities and Warfare: The Impact of Terrorism on Urban Form." Journal of Urban Economics, 51: 205-24.

Greif, A. and G. Tabellini (2010). "Cultural and Institutional Bifurcation: China and Europe Compared." American Economic Review Papers and Proceedings, 100: 135-40.

Guiso, L., P. Sapienza, and L. Zingales (2008). “Long-Term Persistence.” NBER Working Paper 14278.

Gutmann, M. (1980). War and Rural Life in the Early Modern Low Countries. Princeton: Princeton University Press.

Hale, J. (1985). War and Society in Renaissance Europe, 1450-1620. Baltimore: Johns Hopkins University Press.

Henderson, V., A. Storeygard, and U. Deichmann (2015). "Has Climate Change Driven Urbanization in Africa?" Working paper, London School of Economics.

Hohenberg, P. and L. Lees (1995). The Making of Urban Europe, 1000-1994. Cambridge: Harvard University Press.

Hsiang, S. (2010). “Temperatures and Cyclones Strongly Associated with Economic Production in the Caribbean and Central America." Proceedings of the National Academy of Sciences, 107: 15367-72.

Iyigun, M., N. Nunn, and N. Qian (2010). “Resources and Conflict in the Run-up to Mod- 
ern Europe." Working paper, University of Colorado.

Jaques, T. (2007). Dictionary of Battles and Sieges. Westport: Greenwood Press.

Jia, R. (2014). "Weather Shocks, Sweet Potatoes, and Peasant Revolts in Historical China." Economic Journal, 124: 92-118.

Livi-Bacci, M. (2000). The Population of Europe. Oxford: Blackwell.

Mann, M. (1986). “The Autonomous Power of the State: Its Origins, Mechanisms, and Results," in J. Hall, ed., States in History, Oxford: Oxford University Press.

Motamed, M., R. Florax, and W. Masters (2014). "Agriculture, Transportation, and the Timing of Urbanization: Global Analysis at the Grid Cell Level." Journal of Economic Growth, 19: 339-68.

Mumford, L. (1961). The City in History. New York: Harcourt Brace.

Nickell, S. (1981). "Biases in dynamic models with fixed effects." Econometrica, 49: 141726.

Nunn, N. and N. Qian (2011). “The Potato's Contribution to Population and Urbanization: Evidence from a Historical Experiment." Quarterly Journal of Economics, 126: 593-650.

O'Brien, P. (2011). “The Nature and Historical Evolution of an Exceptional Fiscal State and Its Possible Significant for the Precocious Commercialization and Industrialization of the British Economy from Cromwell to Nelson." Economic History Review, 64: 408-46.

O'Callaghan, J. (2002). “Reconquest and Repopulation.” In M. Gerli, ed., Medieval Iberia: An Encyclopedia, London: Routledge.

Onorato, M., K. Scheve, and D. Stasavage (2014). "Technology and the Era of the Mass Army." Journal of Economic History, 74: 449-81.

Parker, G. (1996). The Military Revolution. Cambridge: Cambridge University Press.

Pirenne, H. (1925). Medieval Cities. This version published in 1969. Princeton: Princeton University Press.

Reid, R. (2012). Warfare in African History. Cambridge: Cambridge University Press.

Reyerson, K. (1999). “Commerce and Communications.” In D. Abulafia, ed., New Cam- 
bridge Medieval History, Volume 5, Cambridge: Cambridge University Press.

Reyerson, K. (2000). “Medieval Walled Space: Urban Development vs. Defense.” In J. Tracy, ed., City Walls, Cambridge: Cambridge University Press.

Rokkan, S. (1975). “Dimensions of State Formation and Nation-Building: A Possible Paradigm for Research on Variations within Europe." In C. Tilly, ed., The Formation of National States in Western Europe, Princeton: Princeton University Press.

Rosenthal, J.L. and R.B. Wong (2011). Before and Beyond Divergence. Cambridge: Harvard University Press.

Shultz, K. and B. Weingast (1998). "Limited Governments, Powerful States." In R. Siverson, ed., Strategic Politicians, Institutions, and Foreign Policy, Ann Arbor: University of Michigan Press.

Smith, A. (1776). The Wealth of Nations. This version published in 2008. Oxford: Oxford University Press.

Stasavage, D. (2011). States of Credit. Princeton: Princeton University Press.

Stasavage, D. (2014). “Was Weber Right? City Autonomy, Political Oligarchy, and the Rise of Europe." American Political Science Review, 108: 337-354.

Tilly, C. (1975). "Reflections on the History of European State-Making," in C. Tilly, ed., The Formation of States in Western Europe, Princeton: Princeton University Press.

Tilly, C. (1992). Coercion, Capital, and European States, 990-1992. Cambridge: Blackwell.

Tracy, J. (2000a). “Introduction.” In J. Tracy, ed., City Walls, Cambridge: Cambridge University Press.

Tracy, J. (2000b). “To Wall or Not to Wall: Evidence from Medieval Germany.” In J. Tracy, ed., City Walls, Cambridge: Cambridge University Press.

Voigtländer, N. and Voth, H.J. (2013a). "The Three Horsemen of Riches: Plague, War, and Urbanization in Early Modern Europe." Review of Economic Studies, 80: 774-811.

Voigtländer, N. and Voth, H.J. (2013b). “Gifts of Mars: Warfare and Europe's Early Rise to Riches." Journal of Economic Perspectives, 27: 165-86. 
Weber, M. (1922). Economy and Society. This version published in 1978. Berekeley: University of California Press.

White, L. (1962). Medieval Technology and Social Change. Oxford: Oxford University Press. Wolfe, M. (2000). “Walled Towns during the French Wars of Religion (1560-1630)." In J. Tracy, ed., City Walls, Cambridge: Cambridge University Press.

Wolfe, M. (2009). Walled Towns and the Shaping of France. New York: Palgrave Macmillan. Wooldridge, J. (2009). Introductory Econometrics Fourth Edition. Mason, OH: Thomson South-Western.

van Bavel, B., M. Bosker, E. Buringh, and J.L. van Zanden (2013). “Economy." In P. Clark, ed., Oxford Handbook of Cities in World History, Oxford: Oxford University Press.

van Zanden, J.L. (2009). The Long Road to the Industrial Revolution. Leiden: Brill.

van Zanden, J.L., M. Bosker, and E. Buringh (2012). "The Rise and Decline of European Parliaments, 1188-1789." Economic History Review, 65: 835-61. 
Table 1: Military Conflicts Comprising the Thirty Years' War

\begin{tabular}{|c|c|c|c|c|}
\hline & Conflict Name & Year & Nearest Settlement & Country \\
\hline 1 & Sablat & 1619 & Budweis & Czech Rep \\
\hline 2 & White Hill & 1620 & Prague & Czech Rep \\
\hline 3 & Fleurus & 1622 & Fleurus & Belgium \\
\hline 4 & Hochst & 1622 & Frankfurt am Main & Germany \\
\hline 5 & Wimpfen & 1622 & Bad Wimpfen & Germany \\
\hline 6 & Stadtlohn & 1623 & Stadtlohn & Germany \\
\hline 7 & Breda & 1624 & Breda & Netherlands \\
\hline 8 & Bridge of Dessau & 1625 & Dessau & Germany \\
\hline 9 & Lutter & 1626 & Lutter am Barenberge & Germany \\
\hline 10 & Stralsund & 1626 & Stralsund & Germany \\
\hline 11 & Wolgast & 1628 & Wolgast & Germany \\
\hline 12 & Madgeburg & $1630-1$ & Madgeburg & Germany \\
\hline 13 & Breitenfeld & 1631 & Leipzig & Germany \\
\hline 14 & Frankfurt (Oder) & 1631 & Frankfurt (Oder) & Germany \\
\hline 15 & Werben & 1631 & Werben (Elbe) & Germany \\
\hline 16 & Lützen & 1632 & Lützen & Germany \\
\hline 17 & Nuremberg & 1632 & Nuremberg & Germany \\
\hline 18 & River Lech & 1632 & Rain & Germany \\
\hline 19 & Nordlingen & 1634 & Nordlingen & Germany \\
\hline 20 & Tornavento & 1636 & Oleggio & Italy \\
\hline 21 & Wittstock & 1636 & Wittstock & Germany \\
\hline 22 & Breda & 1637 & Breda & Netherlands \\
\hline 23 & Leucate & 1637 & Leucate & France \\
\hline 24 & Breisach & 1638 & Breisach & Germany \\
\hline 25 & Fuenterrabia & 1638 & Hondarribia & Spain \\
\hline 26 & Rheinfelden & 1638 & Rheinfelden & Switzerland \\
\hline 27 & Casale & 1640 & Casale Monferrato & Italy \\
\hline 28 & 2nd Breitenfeld & 1642 & Leipzig & Germany \\
\hline 29 & Lérida & 1642 & Lérida & Spain \\
\hline 30 & Rocroi & 1643 & Rocroi & France \\
\hline 31 & Freiburg & 1644 & Freiburg im Breisgau & Germany \\
\hline 32 & Allerheim & 1645 & Allerheim & Germany \\
\hline 33 & Jankau & 1645 & Jankov & Czech Rep \\
\hline 34 & Mergentheim & 1645 & Bad Mergentheim & Germany \\
\hline 35 & Lérida & 1647 & Lérida & Spain \\
\hline 36 & Lens & 1648 & Lens & France \\
\hline 37 & Zusmarshausen & 1648 & Zusmarshausen & Germany \\
\hline
\end{tabular}

Source: Clodfelter (2002). 
Table 2: Military Conflicts, 800-1799

\begin{tabular}{lcccccccccc}
\hline & $800 \mathrm{~s}$ & $900 \mathrm{~s}$ & $1000 \mathrm{~s}$ & $1100 \mathrm{~s}$ & $1200 \mathrm{~s}$ & $1300 \mathrm{~s}$ & $1400 \mathrm{~s}$ & $1500 \mathrm{~s}$ & $1600 \mathrm{~s}$ & $1700 \mathrm{~s}$ \\
\hline No of conflicts & 26 & 15 & 50 & 35 & 29 & 51 & 72 & 117 & 157 & 295 \\
City share & 0.12 & 0.09 & 0.27 & 0.14 & 0.19 & 0.20 & 0.29 & 0.39 & 0.45 & 0.54 \\
Grid cell share & 0.08 & 0.06 & 0.15 & 0.11 & 0.11 & 0.15 & 0.18 & 0.28 & 0.35 & 0.43 \\
\hline
\end{tabular}

Sources: Bradbury (2004) for 800-1499 and Clodfelter (2002) for 1500-1799.

Note: Land-based conflicts in Europe. City share is share of sample cities that saw (at least one) conflict by century. Grid cell share is share of sample grid cells that saw (at least one) conflict by century. See Section 3 for further details. 
Table 3: Military Conflict and City Population Growth: Main Results

\begin{tabular}{lcccc}
\hline & $(1)$ & $(2)$ & $(3)$ & $(4)$ \\
\hline \multirow{5}{*}{ Dep var is log city population } \\
& $0.113^{* * *}$ & $0.112^{* * *}$ & $0.063^{*}$ & $0.067^{* *}$ \\
& $(0.039)$ & $(0.038)$ & $(0.033)$ & $(0.031)$ \\
& {$[0.004]$} & {$[0.004]$} & {$[0.055]$} & {$[0.031]$} \\
City FE & Yes & Yes & Yes & Yes \\
Century FE & Yes & Yes & Yes & Yes \\
Country x century FE & No & Yes & Yes & Yes \\
Grid cell time trends & No & No & Yes & Yes \\
Initial log city pop x century FE & No & No & No & Yes \\
R-squared & 0.250 & 0.409 & 0.578 & 0.655 \\
Observations & 3,416 & 3,416 & 3,416 & 3,416 \\
\hline
\end{tabular}

Note: Estimation method is OLS. All regressions include city and century fixed effects. Robust standard errors clustered at grid cell level in parentheses, followed by corresponding $\mathrm{p}$-values in brackets.

*** $\mathrm{p}<0.01,{ }^{* *} \mathrm{p}<0.05,{ }^{*} \mathrm{p}<0.10$ 
Table 4: Military Conflict and City Population Growth: Controls for Observables

\begin{tabular}{lcccccccc}
\hline & $(1)$ & $(2)$ & $(3)$ & $(4)$ & $(5)$ & $(6)$ & $(7)$ \\
\hline \multirow{7}{c}{ Dependent variable is log city population } \\
& $0.073^{* *}$ & $0.066^{* *}$ & $0.062^{* *}$ & $0.067^{* *}$ & $0.062^{* *}$ & $0.051^{*}$ & $0.045^{*}$ \\
& $(0.030)$ & $(0.031)$ & $(0.030)$ & $(0.031)$ & $(0.027)$ & $(0.029)$ & $(0.026)$ \\
& {$[0.016]$} & {$[0.033]$} & {$[0.036]$} & {$[0.030]$} & {$[0.022]$} & {$[0.080]$} & {$[0.082]$} \\
Atlantic port x century FE & Yes & No & No & No & Yes & No & Yes \\
Soil quality x century FE & No & Yes & No & No & Yes & No & Yes \\
Potato suitability x century FE & No & No & Yes & No & Yes & No & Yes \\
Ruggedness x century FE & No & No & No & Yes & Yes & No & Yes \\
Local geography x century FE & No & No & No & No & Yes & No & Yes \\
City-level controls & No & No & No & No & No & Yes & Yes \\
R-squared & 0.664 & 0.657 & 0.657 & 0.656 & 0.685 & 0.663 & 0.692 \\
Observations & 3,416 & 3,416 & 3,416 & 3,416 & 3,416 & 3,416 & 3,416 \\
\hline
\end{tabular}

Note: Estimation method is OLS. All regressions include city and century fixed effects, countrycentury interaction effects, grid-cell specific trends, and initial log city population-century interaction effects. Local geographic controls for seaports, riverports, Roman road hubs, and elevations above sea level. City-level controls for urban networks and centuries for which cities were self-governing communes, university hosts, or bishop or archbishop seats. Robust standard errors clustered at grid cell level in parentheses, followed by corresponding p-values in brackets.

${ }^{* * *} \mathrm{p}<0.01,{ }^{* *} \mathrm{p}<0.05,{ }^{*} \mathrm{p}<0.10$ 
Table 5: Military Conflict and City Pop Growth: Placebos

\begin{tabular}{lcccccc}
\hline & $(1)$ & $(2)$ & $(3)$ & $(4)$ & $(5)$ \\
\hline & \multicolumn{5}{c}{ Dep var is log city } \\
Future conflict exposure & 0.036 & 0.027 & 0.024 & 0.037 & 0.010 \\
(100-yr placebo) & $(0.034)$ & $(0.034)$ & $(0.036)$ & $(0.031)$ & $(0.036)$ \\
& {$[0.281]$} & {$[0.419]$} & {$[0.502]$} & {$[0.238]$} & {$[0.789]$} \\
Exclude capital city, largest city today & No & Yes & No & No & No \\
Exclude 10 largest cities per century & No & No & Yes & No & No \\
Exclude 20 largest cities per century & No & No & No & Yes & No \\
Include self-governing communes only & No & No & No & No & Yes \\
R-squared & 0.603 & 0.591 & 0.607 & 0.617 & 0.640 \\
Observations & 2,743 & 2,594 & 2,647 & 2,548 & 1,885 \\
\hline
\end{tabular}

Note: Estimation method is OLS. All regressions include city and century fixed effects, country-century interaction effects, grid-cell specific trends, and initial log city population-century interaction effects. Robust standard errors clustered at grid cell level in parentheses, followed by corresponding $\mathrm{p}$-values in brackets.

${ }^{* * *} \mathrm{p}<0.01,{ }^{* *} \mathrm{p}<0.05,{ }^{*} \mathrm{p}<0.10$ 
Table 6: Military Conflict and City Pop Growth: Target Effect

\begin{tabular}{lccccccc}
\hline & $(1)$ & $(2)$ & $(3)$ & $(4)$ & $(5)$ & $(6)$ \\
\hline & 0.027 & 0.039 & 0.022 & 0.021 & 0.030 & 0.008 \\
& $(0.025)$ & $(0.031)$ & $(0.028)$ & $(0.027)$ & $(0.026)$ & $(0.029)$ \\
& {$[0.284]$} & {$[0.206]$} & {$[0.421]$} & {$[0.434]$} & {$[0.251]$} & {$[0.789]$} \\
Log city population (first lag) & & -0.018 & & & & \\
& & $(0.031)$ & & & & \\
Exclude capital city, largest city today & No & No & Yes & No & No & No \\
Exclude 10 largest cities per century & No & No & No & Yes & No & No \\
Exclude 20 largest cities per century & No & No & No & No & Yes & No \\
Include self-governing communes only & No & No & No & No & No & Yes \\
R-squared & 0.441 & 0.474 & 0.423 & 0.447 & 0.455 & 0.474 \\
Observations & 2,743 & 2,137 & 2,594 & 2,655 & 2,564 & 1,885 \\
\hline
\end{tabular}

Note: Estimation method is OLS. All regressions include city and century fixed effects, countrycentury interaction effects, grid-cell specific trends, and initial log city population-century interaction effects. Robust standard errors clustered at grid cell level in parentheses, followed by corresponding $\mathrm{p}$-values in brackets.

${ }^{* * *} \mathrm{p}<0.01,{ }^{* *} \mathrm{p}<0.05,{ }^{*} \mathrm{p}<0.10$ 
Table 7: Military Conflict and City Population Growth: Alternative Samples

\begin{tabular}{|c|c|c|c|c|}
\hline & $(1)$ & (2) & (3) & (4) \\
\hline \multirow{5}{*}{ Conflict exposure } & \multicolumn{4}{|c|}{ Dependent variable is log city population } \\
\hline & Exclude British cities & Exclude capital grids & 800-1699 sample & 1400-1799 sample \\
\hline & $0.075^{* *}$ & $0.108^{* * *}$ & $0.072^{* *}$ & $0.051^{*}$ \\
\hline & $(0.031)$ & $(0.033)$ & $(0.031)$ & $(0.028)$ \\
\hline & [0.017] & [0.001] & [0.022] & [0.072] \\
\hline R-squared & 0.625 & 0.670 & 0.605 & 0.663 \\
\hline Observations & 3,027 & 2,696 & 2,743 & 2,292 \\
\hline
\end{tabular}

Note: Estimation method is OLS. All regressions include city and century fixed effects, country-century interaction effects, grid-cell specific trends, and initial log city population-century interaction effects. Robust standard errors clustered at grid cell level in parentheses, followed by corresponding $\mathrm{p}$-values in brackets.

${ }^{* * *} \mathrm{p}<0.01,{ }^{* *} \mathrm{p}<0.05,{ }^{*} \mathrm{p}<0.10$ 
Table 8: Military Conflict and City Pop Growth: Ordered Variable

\begin{tabular}{lcccc}
\hline & $(1)$ & $(2)$ & $(3)$ & $(4)$ \\
\hline \multirow{4}{*}{ Dep var is log city population } \\
& $0.055^{*}$ & $0.063^{* *}$ & $0.038^{*}$ & $0.040^{* *}$ \\
& $(0.028)$ & $(0.025)$ & $(0.020)$ & $(0.019)$ \\
& {$[0.053]$} & {$[0.012]$} & {$[0.057]$} & {$[0.039]$} \\
City FE & Yes & Yes & Yes & Yes \\
Century FE & Yes & Yes & Yes & Yes \\
Country x century FE & No & Yes & Yes & Yes \\
Grid cell time trends & No & No & Yes & Yes \\
Initial log city pop x century FE & No & No & No & Yes \\
R-squared & 0.248 & 0.409 & 0.577 & 0.655 \\
Observations & 3,416 & 3,416 & 3,416 & 3,416 \\
\hline Note: Estimation
\end{tabular}

Note: Estimation method is OLS. All regressions include city and century fixed effects. Robust standard errors clustered at grid cell level in parentheses, followed by corresponding $\mathrm{p}$-values in brackets.

${ }^{* * *} \mathrm{p}<0.01,{ }^{* *} \mathrm{p}<0.05,{ }^{*} \mathrm{p}<0.10$ 
Table 9: Military Conflict and City Pop Growth: Conflict Types

\begin{tabular}{|c|c|c|}
\hline & (1) & (2) \\
\hline \multirow{5}{*}{ Conflict exposure } & \multicolumn{2}{|c|}{ Dep var is log city population } \\
\hline & Battles only & Sieges only \\
\hline & $0.065^{* *}$ & 0.034 \\
\hline & $(0.030)$ & $(0.031)$ \\
\hline & {$[0.033]$} & {$[0.263]$} \\
\hline R-squared & 0.655 & 0.654 \\
\hline Observations & 3,416 & 3,416 \\
\hline
\end{tabular}

Note: Estimation method is OLS. All regressions include city and century fixed effects, country-century interaction effects, grid-cell specific trends, and initial log city populationcentury interaction effects. Robust standard errors clustered at grid cell level in parentheses, followed by corresponding p-values in brackets.

${ }^{* * *} \mathrm{p}<0.01,{ }^{* *} \mathrm{p}<0.05,{ }^{*} \mathrm{p}<0.10$ 
Figure 1: Conflict (Circle) and City (Triangle) Locations, 800-1799

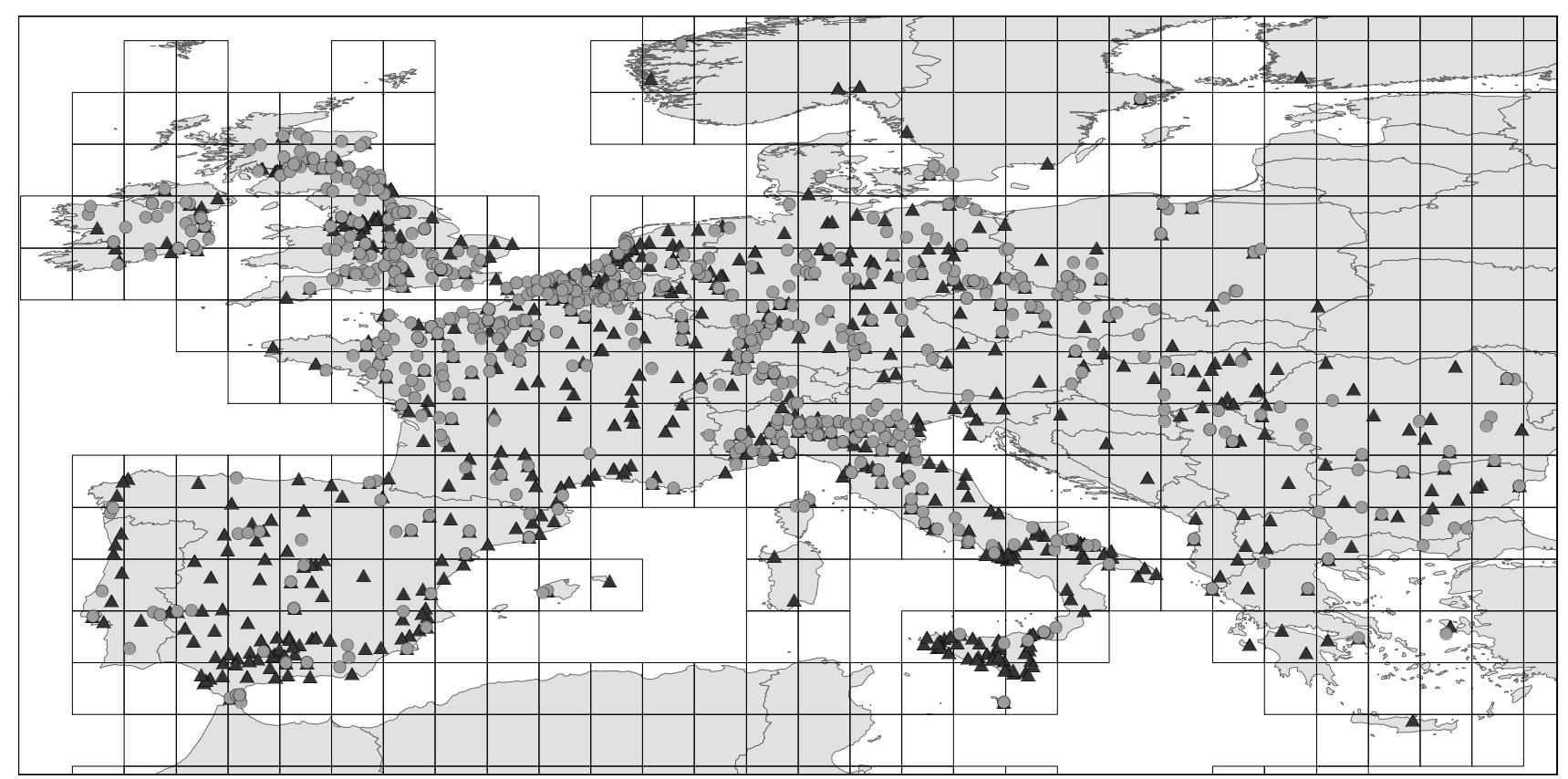

Note: Cylindrical equal area map projection with geometric center (longitude, latitude $)=(10.00735$, 46.76396). Data displayed in projection of analysis. 
Figure 2: Historical Warfare and City Walls in Germany, 800-1799

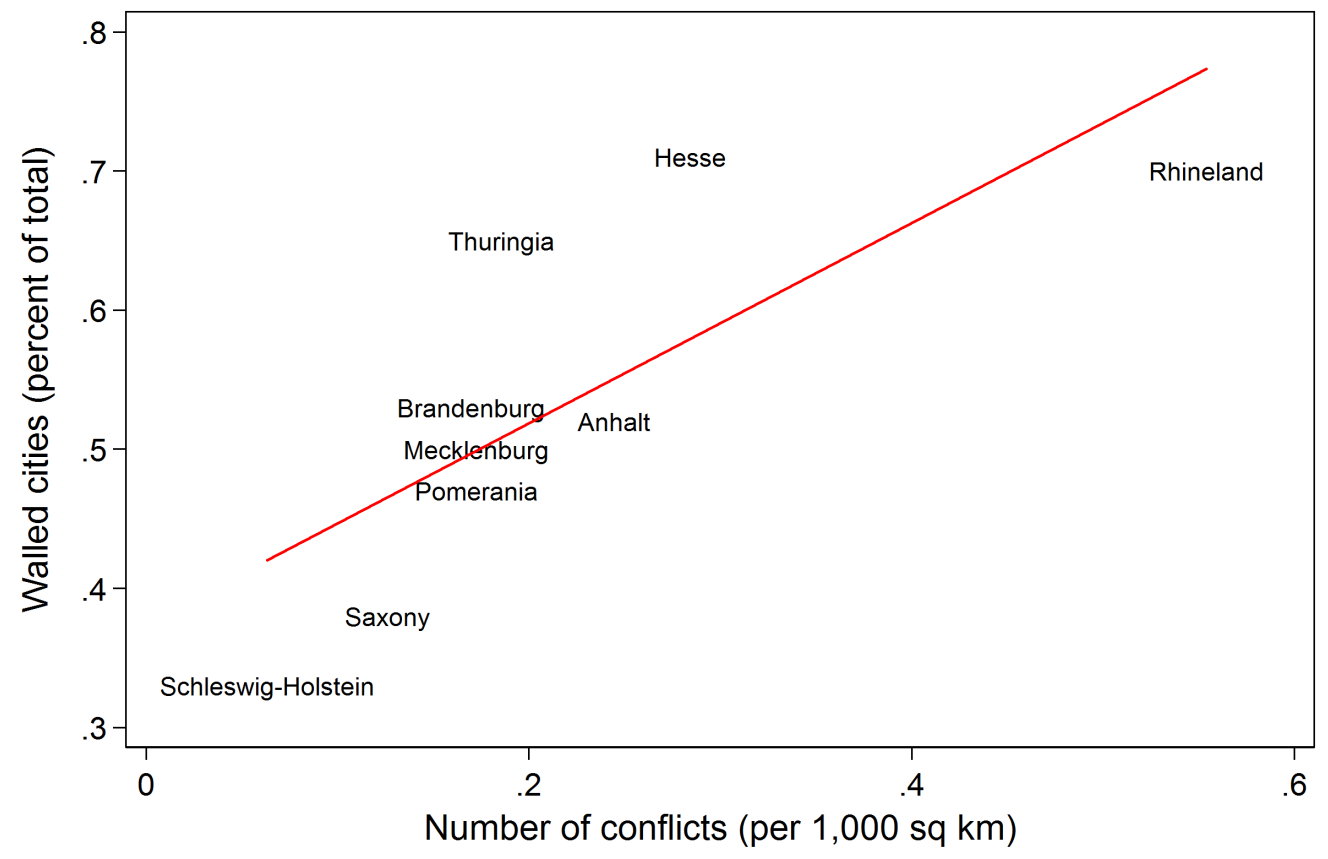

